\title{
Cultural sustainability and community water management in coastal Ecuador: jagüeyes or albarradas and small dams or detention ponds
}

\author{
Sustentabilidad cultural y gestión comunal del agua en la costa \\ de Ecuador: jagüeyes o albarradas y tapes o represas
}

Silvia G. Álvarez Litben ${ }^{a}$

${ }^{a}$ PhD in Anthropology, Associate Professor, Departamento de Antropología Social y Cultural, Universidad Autónoma de Barcelona, Spain Email: silvia.alvarez@uab.cat

doi:10.18472/SustDeb.v12n1.2021.35516

Received: 10/12/2020

Accepted: 02/03/2021

ARTICLE - VARIA

\begin{abstract}
The objective of this article is to highlight the sustainability capacity of pre-Columbian water management systems called jagüeyes or albarradas (detention ponds) compared with modern technologies like dams which are used today in coastal Ecuador. These are compared using interdisciplinary field research, which included ethnographic fieldwork with an observation of participative action projects and a literature review. In the case of tapes (arroyo or small river dams made by farmers or farm owners), the lack of participation and inclusion of social actors and their cultural knowledge about nature is evident. This regional study underlines how the albarradas system achieves long-term sustainability because it is an appropriate technology for the local communal ecosystem with which it is associated. This experience opens up the opportunity to explore the difference between what is currently promoted as sustainability and an alternative form of sustainability which introduces the sociocultural strand in public actions on environmental intervention.
\end{abstract}

Keywords: Water. Sustainability. Detention ponds. Small dams. Public policies. Environmental intervention.

\section{RESUMEN}

El articulo tiene como objetivo resaltar la capacidad de sustentabilidad de sistemas de agua prehispánicos denominados jagueyes o albarradas frente a las modernas tecnologías de represas en la costa de Ecuador. Se los compara a partir de investigaciones interdisciplinarias que incluyeron el método de trabajo de campo etnográfico, con observaciones en proyectos de acción participativa, y revisión de literatura vinculante. Para el caso de los tapes resalta la falta de participación e inclusión de los actores sociales y sus saberes culturales en relación con la naturaleza. El estudio regional subraya cómo el sistema de albarradas consigue sustentabilidad por ser una tecnología apropiada al ecosistema que se asocia al patrón comunal local. Recuperando esta experiencia se discute la conveniencia de diferenciar entre sostenible y sustentable introduciendo el ámbito sociocultural en las acciones públicas de intervención ambiental.

Palabras clave: Agua. Sustentabilidad. Albarradas. Tapes. Políticas públicas. Intervención ambiental. 


\section{INTRODUCTION}

Rural communities in Ecuador's Península de Santa Elena ${ }^{1}$ (PSE) benefit from an extensive number of pre-Columbian jagüeyes (pools or wells), which collect freshwater from rainfall and renew the water table. This water technology was developed at least 3800 years ago and is still in use today, supporting the region's socio-cultural and environmental reproduction (MARCOS, 1995, 2000, 2004).

Interdisciplinary research carried out in a region of over $6000 \mathrm{~km}^{2}$ resulted in the design of a theoretical model detailing the environmental and socio-cultural roles of this complex water management system. This model was implemented and tested in several interventions throughout the region with significant achievements both in the physical recovery of albarradas and in the recovery of ancestral knowledge still current today in the communities concerned (ÁLVAREZ et al., 2013; ÁLVAREZ LITBEN, 2013; ÁLVAREZ; ZULAICA, 2015; MARCOS et al., 2011).

Sustainability indicators were analysed using gathered information, and ethnographic fieldwork methods, including participant observation and interviews during the participative intervention (ÁLVAREZ; ZULAICA, 2015). The ecosystemic services which they provide were subsequently described (ZULAICA; ÁLVAREZ, 2016). One of the objectives of this article, built upon these earlier studies and the literature review, is to understand how what is currently deemed sustainable and what would be sustainable long term are being considered in public policy.

Literature review on collective or community water management and administration projects, and analyses on the use of these terms highlight the importance of including the sociocultural strand in public policies on environmental intervention. The study of cases in a particular region can help us rise to this challenge by testing the concept of sustainability when planning public interventions in general.

Numerous cases researched by Ostrom (2000) display the significance and challenges of managing communal resources, and the strategies and forms of institutional organisations, operating rules, or legal instruments devised to manage these resources successfully without the need for state control or full market intervention.

Our specific objectives involve answering these questions: Physical and ecological considerations aside, why do albarradas persist over the centuries, holding their own against new infrastructures driven by modernising projects? Is their survival related to the communal cultural model to which their management is associated? Is it due to the capacity for collective action evidenced by part of the rural community to survive without state support? Or, on the contrary, are communities prevented from acting with autonomy and independence by a lack of specific knowledge around tapes and dams, designed and built by the modern state? Compared to jagüeyes and albarradas, modern infrastructure seems not to have the same level of support or cultural significance as a common resource for public use which needs to be protected and preserved to secure actual environmental sustainability in the region 


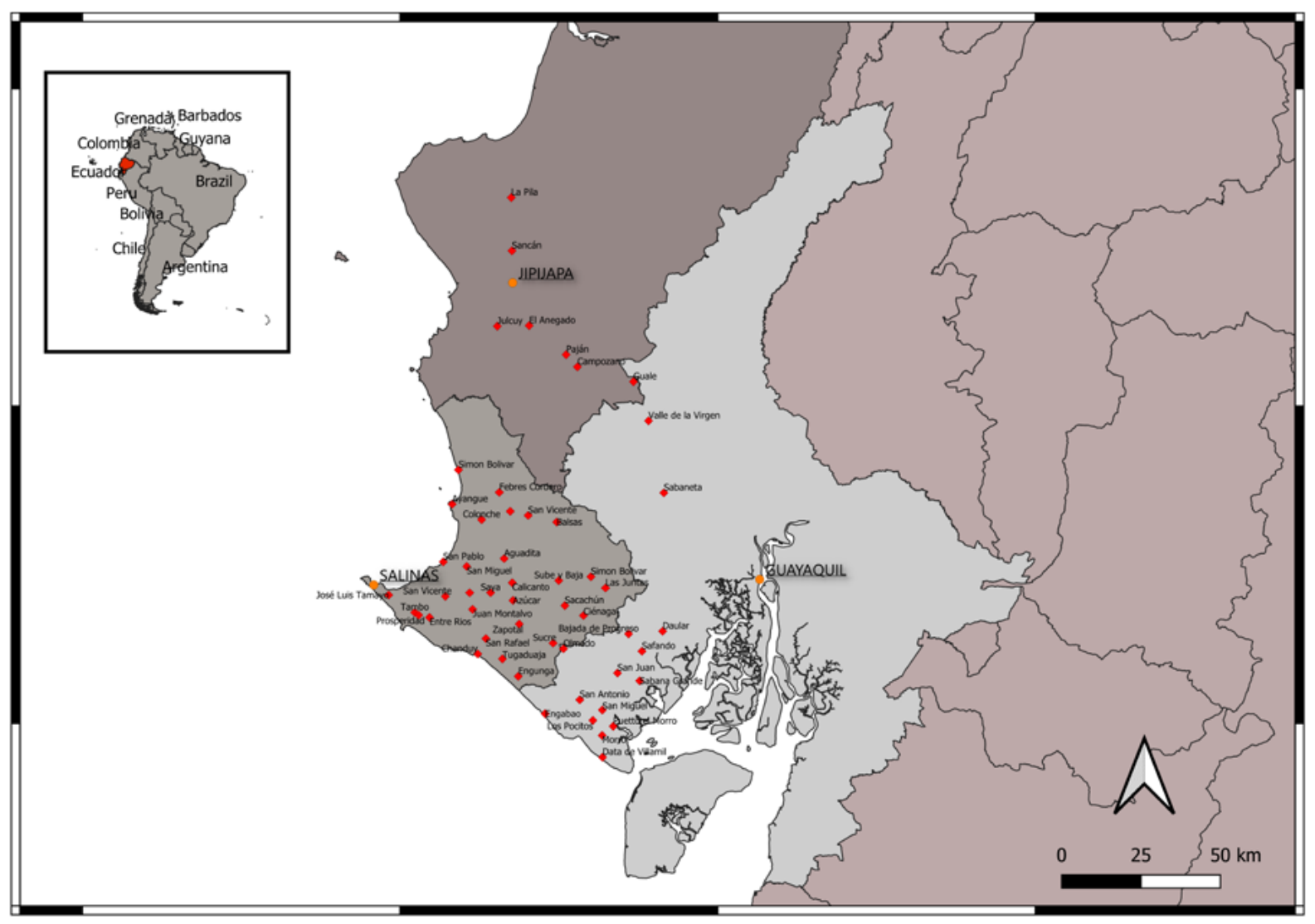

Figure 1 | Península de Santa Elena, Ecuador. Inventory of albarradas systems.

\section{Source: Proyecto Albarradas, 2004}

\subsection{JAGÜEYES OR ALBARRADAS, SMALL DAMS AND DETENTION PONDS: TECHNOLOGIES WITH DIFFERENT PURPOSES.}

The first systematic inventory in 2001 which included the province of Guayas and the southern area of Manabí (Ecuador), registered 252 albarradas. Most of these, 194 (77\%), were on communal land and either operational or in good condition because of maintenance work, while 51 of them (20\%) were not operational and for 7 of them (3\%), no precise data was reported (MARCOS, 2004). Most of the comunas (communes) included in the study (63) across 95 visited sites are located in the lowlands dry scrub eco-region, which has a total of 66 albarradas according to Valverde (2004). This shows the need this area has for water provision.

The inventory also includes 87 (100\%) tapes: $16(18.3 \%)$ collectively-managed and 18 (20.6\%) privatelyowned ones were operational, $46(52.8 \%)$ collective ones and $6(6.8 \%)$ private ones were destroyed, and there is no data on the 1 remaining tape. This means that, out of the total number of tapes built in modern times, 52 (59.8\%) were destroyed, mainly due to harsh winter weather, bad location, and the impact of El Niño in 1982-83 and 1997-98, after which repairing them was deemed too costly in most cases. The parishes with the highest registered number of destroyed tapes are Chanduy (15), Colonche (13) and Santa Elena (11) (MARCOS, 2004).

The fact that $20 \%$ of albarradas were not optimally functioning is linked to the weakened capacity for community management. It results from the loss of labour caused by migration to urban centres and farms, conflict and internal division and the fragmentation of old indigenous lands triggered by the Ley de Comunas (Communes Act) which prevented the organisation of volunteer squads for the periodic maintenance of albarradas (MARCOS; BAZURCO, 2006). In these cases, the comunas cannot invest in integral or large-scale works to be done by the state to secure the system physical sustainability. 
There is no doubt state absence in these contexts, and the promotion of development-focused projects based on agricultural exports and tourism (extractive production, monocultures with high market demand, real estate with large condominiums in the communal coastal belt, backing of business corporations) enhanced the defencelessness of these communities. Despite the request for help, the repair of albarradas is not included in the intervention plans and rather, works such as large transfers or medium-sized tapes are proposed (GONZÁLEZ ANDRICAIN, 2010; PAZ Y MIÑO, 2012).

Other contributing factors to this loss of environmental support are internal conflicts, the weakening of the social fabric, organisational destructuring, and the advancement of market forces that drive the individual model above the collective one. That is the case for the Comuna Manantial de Chanduy, which has not only sold most of its land but also abandoned its ancestral albarrada of Enyamuco2, allowing interventions that have rendered it unusable.

\subsubsection{ANCESTRAL KNOWLEDGE AND MODERNITY: WATER SYSTEMS AND WORLD VIEWS.}

Systems of albarradas and dams coexist in the context of ethnic territories managed by community organisations in most of the PSE area. These spaces and their resources are collectively owned by native families who manage them as a common resource (OSTROM, 2000). They invest time, effort and attention in the maintenance and defence of their land, an essential space for social and economic reproduction which, despite having adapted to market requirements, remains the population's main ethnic marker (ÁLVAREZ, 1999, 2010).

As a physical structure, albarradas have low and compact walls and are built within flat areas away from river courses to avoid being destroyed. They fill up slowly with rainwater in the winter season and collect water that seeps through the selected permeable or semi-permeable soils. These systems have been identified as ancestral forms of "water nurturing" in fragile areas throughout the Andean region (KASHYAPA, 2013). Thus, their design has not only guaranteed water in sufficient quantity and quality for consumption. It has also helped with the renewal, collection and storage of water to refill aquifers and support the renewal of forests and life in the surrounding areas (MARCOS, 1995, 2004). These benefits are essential in an environment under severe threat from both environmental and climatic factors on the one hand, and the extractive activities operating in the region on the other.

After World War II, "modern" water structures called tapes or small dams proliferated. These structures aim to fulfil the same purpose of supplying water, but they do so through a rapid water collection process involving damming up a tributary, stream or basin. However, when facing El Niño or rainy winters, most of them are destroyed by an increase in water volume and power.

The main contribution of ancestral technology is that it secures water for social and economic renewal by applying traditional knowledge to the community's ecological practices and cultural values (ÁLVAREZ, 2006, 2010; MILLAN-ROJAS et al., 2016). Furthermore, at a local level, ancestral technology also benefits the existence of spiritual beings, such as the male and female spirits, with whom it coexists (BURMESTER, 2011), an idea which is similar to the cosmovision shared by other forest dwellers (KHON, 2021). Water has been seen as a vital element since time immemorial, as has the environment people inhabit. It is distributed equitably and horizontally in the context of a social organisation which is communal, where land and resources are considered a common asset and private property do not exist. Socioculturally, albarradas systems are a reference point for the memory, identity and collective values of the native population. These systems are part of their cosmovision and their ethical relationship of coexistence with nature (GÓMEZ MUÑOZ, 2000). 
On the other hand, tapes have an essentially productivist and commercial role stemming from the resource-oriented perspective of modernisation, which aims to obtain large amounts of water in a short period and secure the profitability of investments or undertakings. This goal responds to a market economy in which the comunas operate at a disadvantage, and includes neither the strengthening of community organisation nor the value of the water's environment among its aims (MARCOS, 2004; MARCOS; ÁLVAREZ, 2014). Those who build tapes pay no consideration in their designs to the renewal of the water table or biodiversity, replicating what has been referred to as "water structuralism" in the management and governance of surface water (CASAJUS, 2009).

The programmes to build large waterworks in the 1980s aimed to change production conditions by irrigating thousands of hectares, turning the region into "Ecuador's granary". However, the results were not as expected, nor did the communal population benefit from those works. Large dams ended up providing services to the oil industry, to private companies and agro-exporters. With unauthorised drilling, they built wells to extract groundwater which fed partly from the albarradas systems. These projects were conceived as part of the development narrative to achieve modernity and progress, but they prioritised extractivism, negatively impacting community water tenure and privatising it in favour of agribusiness (ÁLVAREZ, 1999; ÁLVAREZ et al., 2004; HIDALGO et al., 2017; SCAZZA, 2017).

While jagüeyes have been preserved over centuries in locations selected by the native population (ÁLVAREZ LITBEN, 2014), the location of tapes follows the criteria of conventional civil engineering, blocking main tributaries with heavy machinery, driven by an exogenous logic and excluding the participation of local stakeholders. There is evidence that a lack of planning by successive governments, both in the construction of tapes and in the locations chosen, had serious implications for the population, the environment and community microeconomics (GONZÁLEZ ANDRICAIN, 2009). An example identified by Paz y Miño (2012) is the tape known as "Albarrada del Pueblo" in Comuna Sacachún, in which the intervention of exclusively external experts led to the felling of trees and the contamination of the water, leaving it unfit for human consumption. Despite the political will expressed by the Secretaría Nacional del Agua (SENAGUA) in 2014 to involve the local community and take into account their knowledge, this tape succumbed after several hours of heavy rain in 2018: the wall gave in, and all accumulated water was lost. The investment required to repair it is out of reach for any comuna ${ }^{3}$.

This relates equally to a lack of strategic planning and reliable information concerning public policies. Some critics pointed to poor management, a lack of previous analysis, a lack of understanding of the reality on the ground in development projects, a disregard for the beneficiaries' opinion, a lack of communication between the various water regulatory bodies, and the hiring of contractors at premium prices for irrigation works (CHAVEZ MONCAYO, 2000; GONZÁLEZ ANDRICAIN, 2009; JACOBSEN, 2010; MENDOZA, 2006; PAZ Y MIÑO, 2012).

When stripped of their technological sovereignty, the population becomes dependent on state intervention and is powerless when faced with the cyclical destruction of tapes. They are unfamiliar with how tapes work and they lack both the necessary machinery to maintain them and the manpower to preserve them. The patronage values and aspirations of progress promoted by the dominant culture become commonplace, favouring macro-technology and alternative water supply sources. This imposition causes the replacement or underuse of the albarradas system in water provision, particularly for domestic use. This has been observed in, amongst others, the comunas Sube y Baja, Pocitos, Olmedo, and El Morro (ÁLVAREZ, 2005). Local politicians and development agencies have promoted a patronage relationship where communities, in exchange for votes, receive visits from engineers and promises of bringing machinery to repair tapes (ÁLVAREZ et al., 2013). 
In some cases, public policies have been willing to incorporate ancestral knowledge and management practices into the restoration and conservation of the albarradas systems and have recognised their value (ÁLVAREZ et al., 2013; MARCOS et al., 2011). Although these are isolated cases, it is important to report them to highlight that public policies are instrumental in acknowledging and supporting the local population's demands regarding their ancestral heritage and their approach to nature.

Ancestral knowledge, updated and influenced by other social knowledge, informs how water and its environment are managed, and is a legacy for the survival and flourishing of the local population and their cultural way of life (BROWNRIGG, 1996). As such, the albarradas system, understood as an expression of heritage in terms of community and gender, becomes a focal point for history and identity, fosters self-esteem and grants autonomy in managing the land and its resources. So we can compare two histories and two approaches to environmental management: that of "the others" versus that of a specific "us", which is collective and inextricably connected to the community sphere (GONZÁLEZ ANDRICAIN, 2009, 2010; MARCOS, 2004, 2011; MARCOS; ÁLVAREZ, 2016; PAZ Y MIÑO, 2012). While the albarradas are a patrimony handed down from ancient times, tapes are delivered by the state as an assistance act, well-intentioned condescendence and unconnected to water social rights.

Local knowledge is gained through experience in water management and administration. It is Kashyapa's idea of "water nurturing" (2013, p. 1). It can contribute to solving the region's current problems. Nevertheless, this rooted in the local cultural fabric knowledge is not fully accepted by formal science and is unintelligible to most white-mestizo society. It, therefore, needs to be acknowledged, valued, integrated and disseminated as an additional source of knowledge ${ }^{5}$.

This is connected to broader conceptions that respond to the capitalist system context and the western culture cosmovision. Dams reflect the artefactual, mechanical thinking stemming from a dualist cultural conception that contraposes society and nature. Very early, Anthropology censured how the West considered nature as an object to be transformed and turned into consumer goods or wealth (JULIANO, 1988). Anthropocentrism is at the root of the idea that culture is separate from nature and this thinking permeates both common sense and scientific practice in our society (DESCOLA, 2011). According to Sullivan (2013), the issues with the commodification of nature took a new turn in the context of the environmental crisis in which the conservation of nature is reinterpreted in monetary and negotiable terms.

This reflects the idea of "water structuralism", which is guided by the modernising paradigm which, from a technocratic perspective, aims to control surface water to benefit profitable activities by using conventional science and technology (CASAJUS, 2009).

However, the development of water megaprojects not only generates disputes over physical resources but also over the imposition of a specific way to view the world, to approach, understand, feel, and think of nature (SCAZZA, 2017; JACOBSEN, 2010). The concept of "development" does not exist in the Andean cosmovision (VITERI, 2002) and in the wisdom of Andean communities, concepts such as certainty, efficacy, environmental services or productive resources have a different weight and meaning. Development tries to displace native ideas on the meaning of good living, identity, heritage, and existential and cultural autonomy (CHIRIF, 2013; VITERI, 2002). Overall, development projects have an impact not only on the sociocultural reality but also on everything that surrounds it (water, plants, animals, rocks). Thus, they break the relationship between society and nature. This shows the incompatibility between two cosmovisions which produce different ways of living.

The albarradas systems have managed to last because this local knowledge proves the stakeholders' ability "to materialise the culturally established articulations between social practice and the environment". It is, therefore, possible to affirm the inseparable relationship between "knowing, being and doing" (SKEWES, 2004, p. 4, own translation). 


\section{ACHIEVING SUSTAINABILITY IN WATER MANAGEMENT}

Since the Brundtland Report (WCED, 1987) raised awareness of the challenge of achieving sustainable development, public and academic policies have aimed to promote a balance between its four strands: ecological, economic, socio-cultural and political.

In Latin America, research, training and action are focussing on helping to achieve a fair distribution of water, to promote policies that are more democratic and more sustainable development practices (e.g., Water Justice, WALIR Programme) ${ }^{4}$. There is evidence the traditional and customary water rights of these communities are not taken into account when economic investments are made in their territories. Communities do not even receive compensation when their access as users is affected (SOLANES, 2015).

Post-extractive transitional projects which do not rely on mining or fossil fuels have been promoted in several countries. This requires a thorough reform of the role of the state and substantial changes in the production and consumption processes (GUDYNAS, 2011). Leaving behind the capitalisation of nature involves a process of social reappropriation, with a new "productive rationality founded in ecological potential and new civilising logic" (LEFF, 1998, p. 28, own translation).

In Ecuador, the protection of nature (Pachamama) and its cultural assets was included in extenso in its 2008 Constitution. In the Constitution, nature is a legal subject holder of rights. One chapter acknowledges water as a fundamental and sovereign human right, to be managed publically or by the community. It names it a strategic national asset (GARCÍA, 2010; ISCH LÓPEZ, 2017; MARTíNEZ, 2010; ZAPATA, 2010). Gudynas (2011) defined this as "super-strong sustainability" (own translation), manifesting a biocentric stance that must be secured in public policy.

The idea of the citizens' right to good living, or Sumak Kawsay, as an alternative philosophy to anthropocentric, Eurocentric and univocal capitalism, was also enshrined (MARAÑóN, 2015). Centralised bodies were set up, such as SENAGUA in 2008, or the Instituto Nacional de Riego (INAR, National Institute for Irrigation) in 2007, to manage water basins and investments in infrastructure relating mostly to irrigation systems (HOOGESTEGER, 2014).

In 2014, a new Ley de Aguas (Water Law) was approved. It claimed that social movements for the management of and access to safe water and irrigation for farming families (ZAPATA, 2008, 2010) were finally legitimized. This legislation, based on the general principles of sustainability, establishes a management policy based on the notion that water is an inalienable human right for all individuals. Thus, it must be managed to ensure this right can be enjoyed by future generations. The articles of this law include the human right to water and the authorities' obligation to respond to this demand by individuals, communities, peoples, nationalities, groups and comunas in Ecuador (LEY ORGÁNICA DE RECURSOS HÍDRICOS, 2014, articles 57 and 58).

However, the constitutional mandate must contend with the intransigence of extractive hard-liners who prioritise forms of production such as open cast mining, business-led, intensive, private and export-focused agriculture, and real estate tourism (ISCH LÓPEZ, 2017). Giving in to those priorities would impose a view of modernity, the rationality of development, individual autonomy, progress and anthropocentric technification, over common ownership, mutual support, tradition, and local ancestral knowledge (JACOBSEN, 2010).

With regards to albarradas systems and tapes, these are included in the public policies and goals set which is published every five years in the Plan Nacional del Buen Vivir (National Plan for Good Living). Although the human right to water has been recognised and governability with local participation has been strengthened, it is obvious that projects are still production- and market-oriented in their management of water resources. 
We agree with Shore (2010) in considering that public policies are an instrumental ideological principle. They do not merely persuade or legitimise actions carried out by governments on their citizens. They are also driven by certain cultural views. We can, therefore, assume that they are translated into social intervention mechanisms that intend to confer on the world a particular appearance. Public policies are conceived as tools used by states to impose their "will to power". They are designed to install new categories of people and new forms of subjectivity following the liberal hegemonic model (APARICIO, 2019; SHORE, 2010).

\section{ON SUSTAINABILITY AND GOVERNABILITY/GOVERNANCE}

To assess the likelihood of achieving sustainability, either as it is currently understood or in a comprehensive sense which incorporates the sociocultural strand, we must consider criticisms made to the debatable content of this concept. According to Obando, the current concept of sustainability

does not incorporate changes in production levels, in ethics, in the concept of nature, the relationship with ecosystems, [...] nor the reduction in the growth of the capitalist system, a system responsible for intensive appropriation of nature and high poverty and inequality rates. (BLANCO OBANDO, 2019, p. 135 and 142, own translation).

Its heterogeneous diversification into various strands of development should also be acknowledged, "where some focus on human needs, others focus on the needs of future generations, others, on the need for conservation of biodiversity, and a few, finally, focus on economic growth" (GUDYNAS, 2011, p. 84, own translation).

When analysing the importance of the four dimensions of sustainability to solve environmental problems, ecological and monetary considerations still prevail over sociocultural ones (DEL CASTILLO et al., 2019). This means that conflicts of interest, differing cultural perceptions of nature, and conflicts between stakeholders are left out. There have been attempts to put a value on ecosystems according to the services they provide to the community as another mechanism to achieve long-term environmental sustainability. However, findings show that the emphasis is still placed on biophysical, economic and ecological matters, leaving sociocultural perception to one side. This is related to the difficulties inherent in estimating the monetary or market value of sociocultural aspects, given the intangible nature of cultural benefits. Tackling those aspects requires an interdisciplinary approach. In certain cases, social bonds with nature seem to be key to achieving the wellbeing associated with holding on to one's identity through traditional practices that contribute towards actual sustainability (BENNETT et al., 2015; CÁCERES et al., 2015; CHAN et al., 2012; KALTENBORN et al., 2017).

Another problem that stands out and which affects both the 2015 "Sustainable Development Goals" and the 2030 "Agenda" is how different language communities interpret and ascribe cultural meaning to the different concepts in use. It can be observed that, in hegemonic discourses, the construction of an economic view of an ecological reality prevails over the promotion of interculturality. However, there is a desire for sustainable development discourse to respond to "the different cultural, political, economic, and historical situations, and in particular the concepts of nature, of human beings, communities, appropriation practices, and forms of belonging" (MEYER; VILSMAIER, 2020, p. 121-122, own translation).

The anthropologist Philippe Descola (2011) shows that the appreciation of nature as an economic and exploitable object is not a universal fact. Rather, it belongs to certain hegemonic thinking that translates into the kind of ecological impacts that environmental sustainability seeks to repair. In other cosmovisions, culture and nature are not separate and the universe is seen as a continuum of human and non-human subjects which interrelate and see reality from different standpoints. 
It is important to include the structural context in which ecological heritage and social stakeholders exist and to which they are subordinated. It is impossible to think in terms of long-term sustainability without taking into account the relationships and interests operating in the local, regional or international political arena. Therefore, incorporating the political dimension of resource governability in terms of decision-making is crucial for collective management.

What is more, the nature of the relationships between the intervening parties must be considered if the aim is to achieve long-term sustainability in resource management. In indigenous societies, one must also consider the ethical, aesthetical and spiritual dimensions that respond to societies' values and cosmovisions. In many cases, these are excluded by public intervention projects (AGUILAR SÁNCHEZ et al., 2006).

While the original definition of sustainable development (WCED, 1987) did not explicitly include the political, ethical and spiritual dimensions, several authors have argued the need to acknowledge them. Our case study leads us to agree with the usefulness of distinguishing the current mainstream idea of sustainability from actual long-term sustainability to secure the relevance of the four strands of sustainability.

Currently, sustainable refers to the support required in terms of operational resources (financial, human, infrastructural, technological, knowledge). However, these elements alone cannot achieve true sustainability. Thus, sustainability would refer to a process of social inclusion permanently under construction, rather than a goal to be achieved in a given time and space. Achieving this type of sustainability requires participation from all stakeholders to negotiate a conscious decision-making process and share responsibilities in the long term (ALLEN, 1996; FERNÁNDEZ, 2000; FERNÁNDEZ et al., 1999; LEFF, 2005, 2009). This means stepping away from exclusively technical solutions and into scenarios that allow for political debate (GUDYNAS, 2011; LEFF, 2005). Hence the demand for concerted management of resources includes a commitment from all intervening parties to reach compromises and agreements in a "negotiation of exchanges" concerning the economic, ecological and socio-cultural dimensions.

This negotiation must include the principle of governability, understood as actions from the state which exercise power and authority over decisions concerning public life, a power that coexists with the capacity to govern outlined by civil society. Governance involves the inner ability to agree on heterogeneous social values and their efficiency and equity criteria, and the goals and needs to which a particular resource is allocated (GONZÁLEZ BARROSO, 2009). Accepting this coexistence would mean increasing the full participation of sociocultural diversity in political equality (LEFF, 2009).

\section{SUSTAINABILITY IN ALBARRADAS SYSTEMS}

In the case of albarradas and tapes built by public bodies, to what extent can community management be more sustainable than state interventions planning? What are the challenges and limitations in each case? What do we mean when we talk about sustainability as it is currently understood or support by resources in community management settings? Does that mean environmental, cultural, social, and political sustainability? Could it be that actual sustainability is only achievable with the necessary support, given the power relationships and disputes over resources that can be observed in the region?

Up to now, the goal of sustainability (as a scenario for participative negotiation in decision making) in a setting where a public asset is managed by the local community has not been compared with settings where the state (through its formal institutions) is responsible for achieving it. 
The potential and the possible conflicts and threats that endanger both the service provided by albarradas and the environmental management pattern that supports them were identified at the interdisciplinary level, considering water as a social asset that facilitates a way of life and that is part of the ecological heritage, rather than as a productive factor (MARCOS, 2004).

The ability to achieve solid sustainability understood as holistic management and reproduction has been identified using a set of quantitative and qualitative indicators applied to a sample of cases from the coastal region (ÁLVAREZ; ZULAICA, 2015). Most favourable situations occur in comunas where social cohesion, participation and community organisation is strong. While these areas are facing serious climate challenges (water shortage and El Niño), the social component determines the systems' survival capacity through ancestral maintenance and restoration practices. The variables taken into account to assess the socio-cultural dimension of this kind of sustainability include accumulated experience in managing and maintaining albarradas, the transmission of knowledge from one generation to the next, participative management of this resource, and the symbolic meanings attributed to it as an ethnic identity marker.

Although risks were identified in the four strands considered (environmental, economic, sociocultural and political), one of the findings of this report is the importance of communal management in the long-term reproduction of these systems. Albarradas would disappear if it were not for the organisational ability and collective willingness to serve expressed by the community. Comunas can mobilise human resources that include, amongst others, formal associations, small neighbour or family support networks, and bonds that transcend the specific territorial framework. All these organisational levels form a powerful social fabric which is key to securing the sustainability of albarradas.

Albarradas are not only more sustainable technologically, in terms of being fully adapted to the environmental characteristics of the dry tropical forest, but they are also a cultural reference point that is familiar and intelligible to the local population. There is a history of social involvement and cultural attachment which guarantees their long-term sustainability and would explain the consensus to preserve them. It is obvious that preservation is due to their socioeconomic bond with the community, but there is also a symbolic bond.

Material sustainability may be due to their efficient construction, geographical location, geological position, and association to dry forests, achieved through local environmental knowledge (ÁLVAREZ LITBEN, 2014). However, their permanent use, i.e., their long-term sustainability, has depended on a conscious decision by the native population.

In a community management setting, actual, long-term sustainability refers to a particular view on life that demands constant cooperation, a cohesive social fabric, and making sufficient joint decisions and commitments to achieve common goals. For albarradas systems, this includes the potential collective work invested in them, the sense of ownership of that common resource, and the awareness of the key ecosystem services which albarradas provide for the good living of the community. These services, the water supply being the main one, contribute to the holistic support of life, given that they are horizontally consumed, enjoyed and shared, thereby generating collective wellbeing (ZULAICA; ÁLVAREZ, 2016).

\section{CONCLUSIONS: SUSTAINABILITY, LOCAL CULTURE, AND PUBLIC POLICIES}

There is an obvious desire to achieve acceptable levels of solid sustainability in the use and management of water and natural resources in coastal Ecuador. The findings of our research show the advantages of albarradas systems over modern technologies such as tapes or small dams. Albarradas have survived over centuries not only because their technology suits the dry tropical forest ecosystem, but because their sociocultural dimension secures their sustainability in the long term. They benefit from being familiar according to tradition, they are part of the fabric of cultural knowledge, and they respond to a 
particular cosmovision concerning humans' relationship with nature. On the other hand, tapes or dams follow a modernising and development-oriented cultural ideal whose individualistic logic lacks both the connection with nature and the perception of those structures as a common resource for public use.

Sustainability's sociocultural dimension is linked to social cohesion, identity, participation and community organisation through the transfer of knowledge, and maintenance and restoration practices. But this dimension is almost non-existent in public policies for environmental intervention.

In our case study, we argue that to achieve long-lasting sustainability, it is beneficial to include ethical and practical ideas concerning local communities' relationship with nature through interdisciplinary approaches. This will raise awareness about communal knowledge and tradition concerning the cultural and ecological dimensions.

We find that stakeholders in the state apparatus are informed by a unilateral viewpoint and end up imposing their cultural perspective on all projects. Public policies do not take into account that various social stakeholders converge on this topic, each with a particular view (indigenous, environmentalist) whereby water is seen as part of an ecosystem, as a living being, and not merely as an economic resource (ISCH LÓPEZ, 2017).

Another strand that appears to be overlooked in intervention projects and analyses is the political one, which includes social stakeholders' relationships and interests. To include it means to acknowledge that actual sustainability, rather than the technology itself (whether modern or ancient) must be understood as the achievement of agreements, consensus, and negotiations on how the various stakeholders involved view life. This perspective clashes with development projects which impose an economic, technocratic and anthropocentric approach It competes not only for natural resources but for the cultural concept. Therefore, incorporating the political dimension of resource governance in terms of decision-making can be crucial for collective or community management.

This paper may help understand that the strategy to achieve sustainability, in the framework of an ethnocentric and extractive cultural pattern geared towards agricultural exports, may seem impossible unless the cultural matrix is transformed. It is hard to imagine interculturality and integration of knowledge without respect towards other ways of life. That is, knowing, acknowledging and valuing the existence of other ways of thinking, with other logics and existential frameworks (LEFF, 2009).

Through our work, we have shown that access to water could be resolved more favourably in many regions by supporting local systems, rather than making large investments in exogenous technology such as tapes or small dams.

This could easily be achieved if the state secured sustainability in its most tangible dimensions (physical and technical) by making the necessary operational resources available regularly and systematically (e.g., machinery). Meanwhile, sustainability in terms of long-term agreements, consensus, and negotiations, would come from the coordinated participation of stakeholders, who would share responsibilities according to their particular view of life. This would incorporate the sociocultural and political strands of sustainability.

For communal resources, this includes a sense of conscious involvement, with ethical, emotional, and spiritual dimensions, based on forms of collaboration and reciprocity, a willingness to serve, and group participation as the foundations of community social fabric. For the state, demands made by these populations can find recognition through public policies, with support and respect for other approaches to nature.

Although there have been changes in daily life and certain practices and skills, the grassroots social organisation remains, and the communal way of life persists despite market pressures. As such, 
sustainability for the proliferation of albarradas systems can still be secured where social cohesion, participation and collective action have proved to be valuable for the population's good living. This is reflected in a catalogue of management practices, customs and approaches to nature that translate into traditions, habits, abilities, and behaviours transferred and shared for generations.

Strategies based on extractivism and development focus on the economy and establish a cultural model with univocal logic and values. Therefore, pursuing a conventional type of sustainable development, leaving untouched how we relate to other existing beings and ignoring local ancestral knowledge, deprives us of the collective ability to bring together our knowledge and practices on sustainability ${ }^{6}$.

\section{NOTES}

${ }^{1}$ This geographical region includes the province of Santa Elena, Guayas and south of Manabí.

${ }^{2}$ Activities developed by PRODEPINE, as part of a Local Development Plan with the Federation of Comunas of Guayas in 2004, which included the rehabilitation of albarradas. Alexander Herrera Wassilowsky (2011) summarises the unsuccessful redesign of this albarrada and how it is currently unusable.

${ }^{3}$ Observations during fieldwork in 2014 and 2018. Álvarez, Varela, and Burmester, 2013 (MS) copies in SENAGUA.

${ }^{4}$ WALIR Programme (Water Law and Indigenous Rights. Wageningen University, UN/CEPAL).

${ }^{5}$ For example, CONECT-e project's interactive platform, promoting the conservation and dissemination of traditional ecological knowledge to acknowledge and boost it. Available at: http://www.conecte.es/.

${ }^{6}$ Translator's note: in the original paper in Spanish, the author distinguishes between "sostenibilidad" and "sustentabilidad", both meaning "sustainability" in English. The nuances attributed to "sustentabilidad" (actual, solid, long-term sustainability that incorporates sociocultural elements) versus "sostenibilidad" (the current mainstream idea of sustainability based on economic terms) have been reflected in the English translation by adding explanatory terms where appropriate.

\section{REFERENCES}

AGUILAR SÁNCHEZ, O. et al. Territorialidad y gobernabilidad indígenas, Codenpe, Quito, 2006.

ALLEN, A. Desarrollo urbano sustentable. Modulo Maestría Gadu, Facultad de Arquitectura, Urbanismo y Diseño, Universidad Nacional de Mar del Plata, Argentina, 1996.

ÁLVAREZ, S. De Huancavilcas a comuneros. Relaciones Interétnicas en la Península de Santa Elena. Quito: AbyaYala - CEAA, ESPOL, 1999.

ÁLVAREZ, S. (Ed.) Comunas y Comunidades con Sistemas de Albarradas. Descripciones Etnográficas, v. 1. (Serie Cultura Comunal, Agua y Biodiversidad en la Costa del Ecuador). Quito: ESPOL - Abya - Yala, 2005.

ÁLVAREZ, S. The Use and Traditional Knowledge of Pre-Hispanic Hydraulic Systems amongst Indigenous and Non-Indigenous Populations on the Ecuadorian Coast. En: JACOBSEN, F. F.; MCNEISH, J. (Ed.). From where life flows: the local knowledge and politics of water in the Andes. Trondeheim: Tapir Academic Press, 2006.

ÁLVAREZ, S. Prácticas, creencias y valores que condicionan la reproducción de los sistemas de albarradas en la Península de Santa Elena. En: ÁLVAREZ, S. (Ed.). v. 4. (Serie Cultura Comunal, Agua y Biodiversidad en la Costa del Ecuador). Quito: ESPOL - Abya - Yala, 2010.

ÁLVAREZ, S.; Varela, N.; Burmester, M. Informes Finales de Consultoría para la rehabilitación de cuatro albarradas en la demarcación hidrográfica de Guayas. Fortalecimiento de iniciativas locales para el uso y aprovechamiento de los recursos hídricos, a través de tecnologías ancestrales. Guayaquil: SENAGUA Ecuador, 2013.

ÁLVAREZ, S. et al. Componente Sociocultural: organización social, cultura y gestión de los Sistemas de Albarradas en la PSE. En: MARCOS, J. (Coord.) CEAA-ESPOL, 2004.

ÁLVAREZ, S.; Zulaica, L. Indicadores de sustentabilidad en sistemas de albarradas: aportes metodológicos. Revista Letras Verdes, n.18, p. 184-207, 2015. 
ÁLVAREZ LITBEN, R. Albarradas: espacialidad y recurrencia en los sistemas de albarradas localizadas en las provincias de Santa Elena y Guayas. Tesis (Maestría en Arqueología del Neotrópico) - Facultad de Ciencias de la Tierra, Espol, Guayaquil, 2014

APARICIO, M. (Ed.). Modernidades contrahegemónicas. Pluralismo jurídico y sistemas normativos indígenas contemporáneos. Barcelona: Icaria, 2019.

BENNETT, E. et al. Linking biodiversity, ecosystem services, and human well-being: three challenges for designing research for sustainability. Current Opinion in Environmental Sustainability, v. 14, p. 76-85, 2015.

BLANCO OBANDO, E. Medio ambiente y desarrollo: resultados ambientales y sociales de la operación de las mayores actividades productivas en la región Atlántico/Caribe de Costa Rica. Revista de Ciencias Sociales. Universidad de Costa Rica, n. 164 (II) 2019.

BROWNRIGG, L. A. Al futuro desde la experiencia. Los pueblos indígenas y el manejo del medio ambiente. Quito: ediciones Abya-Yala, 1996.

BURMESTER, M. La presencia del mundo simbólico en la intervención ambiental en la costa del Ecuador. Ponencia en: Terceras Jornadas del Mercosur sobre Patrimonio Intangible, Mar del Plata, 13 y el 16 de abril, 2011.

CÁCERES, D. M. et al. The social value of biodiversity and ecosystem services from the perspectives of different social actors. Ecology and Society, v. 20, p. 62-81, 2015. Disponible en: <https://ri.conicet. gov. ar/bitstream/handle/11336/22497/CONICET_Digital_Nro.85402f34-41f8-446c-a897-d3dc3f17cc03_A. pdf?sequence=2\&isAllowed=y Acceso 10 de mayo 2020

CASAJUS MURILLO, M. L. Nuevos Paradigmas en la Gestión del Agua en España. Crisis de Gobernabilidad del Agua en Aragón. Los Conflictos de Yesa y Matarraña. Tesis (Doctoral) - Universidad Autónoma de Barcelona, España, 2009.

CHAN, K. M. A.; SATTERFIELD, T.; GOLDSTEIN, J. Rethinking ecosystem services to better address and navigate cultural values. Ecological Economics, Elsevier, v. 74, p. 8-18, 2012.

CHÁVEZ MONCAYO, M. Análisis de los daños provocados por el Fenómeno El Niño en la infraestructura de la costa ecuatoriana. Conferencia. Área Tecnologías, Proyecto VLIR Bélgica-ESPOL (MS), 2000.

CHIRIF, A. Sobre el desarrollo: cuando la palabra significa otra cosa. Ideele Revista, 232. 2013. Disponible en: $<$ https://revistaideele.com/ideele/content/sobre-el-desarrollo-cuando-la-palabra-significa-otra-cosa>. Acceso en: 10 mayo 2020.

DEL CASTILLO, D. et al. ¿Qué lugar ocupan actores sociales en el contexto de servicios ecosistémicos? Una revisión en áreas de ecología y biología de la conservacion Disponible en Sostenibilidad en: Debate - Brasília, v. 10, n.1, p. 116-131, abr/2019. https://periodicos.unb.br/index.php/sust/article/view/19986 Acceso en: 20 mar. 2020.

DESCOLA, P. Más allá de la naturaleza y la cultura. En: Cultura y Naturaleza. Aproximaciones a propósito del bicentenario de la independencia de Colombia. Martínez, L. M. (Ed.), p. 75, 2011 (en línea) http://www.ceapedi. com.ar/imagenes/biblioteca/libreria/393.pdf>. Acceso en: 10 mayo 2020. Fernández, R. La ciudad verde. Teoría de la gestión ambiental urbana. Buenos Aires: Espacio editorial-CIAM, 2000.

FERNÁNDEZ, R. et al. Territorio, sociedad y desarrollo sustentable. Buenos Aires: Espacio editorial-CIAM, 1999.

GARCÍA, D. Una Constitución hecha de agua. En: ACOSTA, A.; MARTínEZ, E. (Comp.). Agua un derecho humano fundamental. Quito: Abya-Yala, 2010 p. 173-202.

GÓMEZ MUÑOZ, M. Saber indígena y medioambiente: experiencias de aprendizaje comunitario. En LEFF, E. (Coord.). La complejidad ambiental, México: Siglo XXI, 2000.

GONZÁLEZ ANDRICAÍN, C. Identidades étnicas en acción. La organización comunal de la Península de Santa Elena ante la Cooperación al Desarrollo. En: ÁLVAREZ, S. (Ed.). v. 3. (Serie Cultura Comunal, Agua y Biodiversidad en la Costa del Ecuador). Quito: Espol - Abya - Yala, 2009. 
GONZÁLEZ ANDRICAÍN, C. Las albarradas: entre el conocimiento local y las políticas de desarrollo. En: ÁLVAREZ, S. (ed.). v. 4. (Serie Cultura Comunal, Agua y Biodiversidad en la Costa del Ecuador). Quito: Espol - Abya - Yala, 2010. p. 135-153.

GONZÁLEZ BARROSO, F. Documentación sobre gerencia pública, del Subgrupo A1, Cuerpo Superior, especialidad de Administración General, de la Administración de la Junta de Comunidades de Castilla-La Mancha, 2009. Disponible en: <https://issuu.com/locutusbn/docs/gerencia_publica>. Acceso: 10 mayo 2020.

GUDYNAS, E. Buen Vivir: germinando alternativas al desarrollo. América Latina en Movimiento, n. 462, 2011.

HERRERA WASSILOWSKY, A. La recuperación de tecnologías indígenas. Arqueología, tecnología y desarrollo en los Andes, Lima: IEP, Universidad de los Andes, Clacso, 2011.

HIDALGO, J. P; BOELENS, R.; ISCH, E. Sistema multipropósito de agua Jaime Roldós Aguilera: el territorio hidrosocial como escenario de disputa y resistencia. En: ARROYO CASTILLO, A.; ISCH LÓPEZ, E. (Ed.). Los caminos del agua, Quito: Abya-Yala, 2017.

HOOGESTERGER, J. Los nuevos sujetos del agua. Organización social y la democratización del agua en los Andes ecuatorianos. (Serie Agua y Sociedad), Sección Justicia Hídrica. Quito: Justicia Hídrica, Abya-Yala, IEP, 2014.

ISCH LÓPEZ, E. Las políticas públicas para la gestión del agua en el Ecuador: tendencias de los últimos treinta años. En: VILA BENITES, G.; BONELLI, C. (Ed.). A contracorriente: agua y conflicto en América Latina. Quito: AbyaYala. p. 301-320. 2017.

JACOBSEN, F. Dos historias acerca del desarrollo en la Península de Santa Elena. En: ÁLVAREZ, S. (Ed.). v. 4. (Serie Cultura Comunal, Agua y Biodiversidad en la Costa del Ecuador). Quito: Espol - Abya - Yala, 2010.

JULIANO, D. Un Dios a nuestra imagen y semejanza: el mito del buen colonizador. En: V Centenario del descubrimiento: historia de un genocidio, Langaiak, 1988.

KALTENBORN, B. P. et al. Ecosystem Services and Cultural Values as Building Blocks for 'The Good life'. A Case Study in the Community of Røst, Lofoten Islands, Norway. Ecological Economics, Elsevier, v. 140, p. 166-176, 2017.

KASHYAPA. A. S. Y. Prácticas ancestrales de crianza de agua como estrategia de adaptación al cambio climático. Disponible en: <https://www.servindi.org/actualidad/87425>. Acceso en: 9 mar. 2020.

KOHN, e. Como piensan los bosques. Hacia una antropología más allá de lo humano. Quito: Ed. Abya-Yala, 2021.

LEFF, E. Saber Ambiental, Sustentabilidad, Racionalidad, Complejidad, Poder. Madrid: Siglo XXI Editores - Unam - Pnuma, 1998.

LEFF, E. La insoportable levedad de la globalización: la capitalización de la naturaleza y las estrategias fatales de la sustentabilidad. Revista Venezolana de Economía y Ciencias Sociales, v. 7, no 1, 2001.

Leff, E. La Geopolítica de la Biodiversidad y el Desarrollo Sustentable: economización del mundo, racionalidad ambiental y reapropiación social de la naturaleza. En: SEMINARIO INTERNACIONAL REG GEN: ALTERNATIVAS GLOBALIZACIÓN, Unesco. 2005. Disponible en: <http://bibliotecavirtual.clacso.org.ar/ar/libros/reggen/pp12. pdf>. Acceso en: 20 nov. 2006.

Leff, E. La Esperanza de un Futuro Sustentable: utopía de la educación ambiental. En: VI CONGRESO IBEROAMERICANO DE EDUCACIÓN AMBIENTAL, San Clemente de Tuyú, Argentina, 17 de septiembre de 2009. Disponible en: <http://www.sustentabilidades.usach.cl/sites/sustentable/files/paginas/05.pdf>. Acceso en: 20 nov. 2010.

LEY ORGÁNICA DE RECURSOS HÍDRICOS. Usos y aprovechamiento del agua. Republica del Ecuador, Asamblea Nacional, Quito, 5 de agosto del 2014.

MARAÑÓN, B. El Buen Vivir: hacia la descolonialidad de la naturaleza. En: PRIMER ENCUENTRO NACIONAL DE PATRIMONIO VIVO, Buenos Aires 2015. Disponible en: <https://es.scribd.com/document/341145261/PrimerEncuentro-Nacional-de-Patrimonio-Vivo>. Acceso en: 20 nov. 2016. 
MARCOS, J. El manejo del agua en el variado medio ambiente del área Septentrional Andina a partir del tercer milenio B.C. En: GUINEA, M.; BOUCHARD J. F.; MARCOS, J. (Ed.). Cultura y Medio Ambiente en el Área Andina Septentrional, v. 21. Quito: Ed. Abya-Yala, 1995.

MARCOS, J. (Coord.). Las Albarradas en la Costa del Ecuador: rescate del conocimiento ancestral del manejo sostenible de la biodiversidad. Guayaquil: Ed. CEAA-Espol, 2004.

MARCOS, J.; ÁLVAREZ LITBEN, R.; Burmester, M. Informe Final al MAGAAP del Proyecto para mitigar los riesgos de sequía o poca pluviosidad invernal en la provincia de Manabí con especial atención a las tecnologías alternativas basadas en saberes tradicionales y ancestrales, Manabí, Ecuador, 2011.

MARCOS, J.; ALVAREZ, S. Campos de camellones y jagüeyes en Ecuador: una visión integral desde la arqueología al presente. Revista Intersecciones en Antropología, n. 17, 2016.

MARCOS, J.; BAZURCO, M. Albarradas y Camellones en la región costera del Antiguo Ecuador. En: VALDEZ, F. (Ed.). Agricultura Ancestral Camellones y Albarradas: contexto social, usos y retos del pasado y del presente. Quito: Ed. Abya-Yala, 2006.

MARTÍNEZ, E. El agua limpia y libre es agua bendita. En: ACOSTA, A.; MARTÍNEZ, E. (Comp.). Agua un derecho humano fundamental. Quito: Ed. Abya-Yala, 2010.

MENDOZA, V. Administración de los Recursos Hídricos en Ecuador. IV REUNIÓN INTERNACIONAL RED DE CONOCIMIENTO LOCAL. Espol, Guayaquil, Ecuador, 29 de mayo, 2006.

MEYER, E.; Vilsmaier, U. Economistic discourses of sustainability: determining moments and the question of alternatives. Sustentabilidade em Debate, v. 11, n. 1, p. 98-124, 2020. https://doi.org/10.18472/sustdeb. v11n1.2020.26663 Acceso en: 20 mar. 2020.

MILLÁN-ROJAS, L. et al. Conocimiento ecológico tradicional de la biodiversidad de bosques en una comunidad matlatzinca, México. Ambiente y Desarrollo, v. 20, n. 38, 2016. Disponible en: <https://revistas.javeriana.edu.co/ index.php/ambienteydesarrollo/issue/view/1014>. Acceso en: 20 ener. 2017.

OSTROM, E. El gobierno de los bienes comunes. México: Unam, CRIM, FCE, [1990] 2000.

PAZ Y MIÑO, M. E. San Biritute: Iluvia, amor y fertilidad. Guayaquil: INPC, Serie Estudios, 2012.

SCAZZA, M. Challenges to indigenous political and socio-economic participation - Land and Water Grabbing in the Peninsula of Santa Elena, Ecuador. In: TOMASELLI, A. et al. (Ed.). Challenges to indigenous political and socioeconomic participation. Eurac Research, Bolzano. Disponible en: <https://air.unimi.it/handle/2434/581719\#. X4OCnWgzY2w>. Acceso en: 23 febr. 2019.

SENPLADES. Plan Nacional de Desarrollo/Plan Nacional para el Buen Vivir 2013-2017. Quito: Secretaría Nacional de Planificación y Desarrollo, 2013.

SKEWES, J. C. Conocimiento Científico y Conocimiento Local: lo que las universidades no saben acerca de lo que actores locales saben. Cinta de Moebio, n. 19, marzo, 2004. Santiago, Chile Disponible en: <https://www.redalyc. org/pdf/101/10101903.pdf>. Acceso en: 9 mar. 2020.

SOLANES, M. Gobernanza y finanzas para la sostenibilidad del agua en América del Sur. Corporación Andina de Fomento, 2015

SULLIVAN, S. Banking nature. The spectacular financialisation of environmental conservation. Antipode, v. 45, p. 198-217, 2013. Disponible en: <https://onlinelibrary.wiley.com/doi/full/10.1111/j.1467-8330.2012.00989.x>. Acceso en: 9 mar. 2020.

VALVERDE, F. de M.; CHOEZ, M.; Reyes, C. Componente Botánico: situación de la biodiversidad en las albarradas y sectores colindantes de la planicie costera de las provincias de Guayas y Manabí. En: Marcos, J. (Coord.). Guayaquil: CEAA-Espol. p. 127-192. 2004. 
VITERI, C. Visión indígena del desarrollo en la Amazonía. Polis, n. 3, 2002. Disponible en: <http://journals. openedition.org/polis/7678>. Acceso en: 9 mar. 2020.

WCED. Our Common Future: the world commission on environment and development. Oxford: Oxford University Press, 1987.

ZAPATA, A. Los derechos de uso y aprovechamiento de las aguas: entre el derecho civil y el derecho administrativo. En: QUINTO ENCUENTRO DEL FORO DE LOS RECURSOS HÍDRICOS. Portoviejo, 2008.

ZAPATA, A. Lo colectivo y el agua: entre los derechos y las prácticas. En: BUSTAMANTE, R. (Ed). Concertación Derechos de agua: estudios y particularidades en Ecuador. Lima: IEP, p. 109-125, 2010.

ZULAICA, L.; ÁlVAREZ, S. Servicios ecosistémicos de las albarradas en la Península de Santa Elena, Ecuador. Revista Etnobiología, v. 14, n. 2, p. 5-19, 2016. 